\title{
PARADIGMA UNDANG-UNDANG DENGAN KONSEP OMNIBUS LAW BERKAITAN DENGAN NORMA HUKUM YANG BERLAKU DI INDONESIA
}

(Paradigm of Law in The Omnibus Law Concept Relating To Legal Norm Applicable in Indonesia)

\author{
Sodikin \\ Fakultas Hukum Universitas Muhammadiyah Jakarta \\ Jl. KH Ahmad Dahlan Cirendeu Ciputat Tangerang Selatan \\ e-mail: sodikin.fh@umj.ac.id
}

Naskah diterima: 12 Februari 2020; revisi: 6 April 2020; disetujui: 6 April 2020

\begin{abstract}
Abstrak
Undang-undang dengan konsep omnibus law dalam dunia ilmu hukum di Indonesia merupakan paradigma baru di bidang hukum. Makna dan sifat hukum dalam konsep omnibus law berbeda dengan makna, sifat dan konsep norma hukum dalam undang-undang yang sudah ada. Konsep omnibus law dapat dimaknai sebagai penyelesaian berbagai pengaturan dalam peraturan perundang-undangan ke dalam satu undang-undang dan konsekuensinya mencabut beberapa aturan hasil penggabungan yang dinyatakan tidak berlaku, baik untuk sebagian maupun secara keseluruhan. Permasalahannya bahwa norma hukum dalam konsep omnibus law tidak sejalan dengan norma hukum yang selama ini berlaku sesuai dengan sistem hukum Indonesia melalui Undang-undang Nomor 12 Tahun 2011 sebagaimana diubah dengan undangundang Nomor 15 Tahun 2019. Permasalahan ini diteliti dengan metode penelitian hukum normatif yang ditujukan untuk menemukan dan merumuskan argumentasi hukum melalui analisis terhadap pokok permasalahan. Pokok permasalahan ini dapat ditemukan dalam kesimpulan bahwa undang-undang dengan konsep omnibus law yang dibuat akan mengubah sistem peraturan perundang-undangan, karena konsep dan teorinya berbeda dengan model hukum dan norma hukum yang selama ini berlaku di Indonesia. Oleh karena itu, apabila pemerintah bersama DPR memaksakan diri membuat undang-undang dengan konsep omnibus law, maka pembentukannya perlu mengikuti proses prolegnas yang normal, ada naskah akademisnya yang baik, tidak tergesa-gesa dengan melibatkan stakeholder dan masyarakat.

Kata kunci: paradigma, omnibus law, norma Hukum.
\end{abstract}

\begin{abstract}
The omnibus law concept is a new paradigm in the field of law studies in Indonesia. The concept of the omnibus law can be interpreted as the settlement of various regulations in the laws and regulations into one law and consequently revoking some of the rules, either in part or in whole. The problem arises when the legal norms in the concept of the omnibus law are not in line with the legal norms that have been applied in the Indonesian legal system through Law Number 12 of 2011 as amended by law Number 15 of 2019. The result is that the law created under the concept of omnibus law will change the legislation system, because the concept and the theory are different from Indonesia legal system. Therefore if the omnibus law concept is forced to apply in Indonesia, this bill must comply with formal procedures for establishing good regulations. Keyword: paradigm, omnibus law, legal norm.
\end{abstract}




\section{A. Pendahuluan}

Undang-undang yang dibuat tentu saja memuat norma atau kaidah hukum yang merupakan patokan atau pedoman dalam berperilaku. Kaidah hukum dapat juga diartikan sebagai patokan atau ukuran ataupun pedoman untuk bersikap dalam hidup, dan apabila ditinjau bentuk hakikatnya, maka kaidah merupakan perumusan suatu pandangan (oordeel) mengenai perikelakuan atau sikap tindak. ${ }^{1}$ Oleh karena itu, kaidah hukum adalah ketentuan yang bermuatan keharusan bagi orang untuk, dalam situasi kemasyarakatan tertentu, melakukan perbuatan tertentu atau larangan melakukan perbuatan tertentu karena tuntutan keadilan menghendaki hal itu, yang dapat dipaksakan secara sah². Dengan demikian, kaidah hukum atau norma hukum adalah sebuah ketentuan ataupun aturan yang diciptakan oleh suatu lembaga berwenang dengan sifat mengikat dan memaksa.

Selain norma hukum yang dipersyaratkan tersebut, persyaratan penting lainnya untuk dapat dikatakan sebagai sebuah undangundang yang baik adalah undang-undang itu harus didasarkan pada prinsip manfaat. Menurut Jeremy Bentham, maximizing happiness and minimizing pains. ${ }^{3}$ Adanya prinsip manfaat tersebut berarti hukum (undang-undang) harus diketahui semua orang, konsisten, pelaksanaannya jelas, sederhana dan ditegakkan secara tegas. ${ }^{4}$ Dengan demikian, pembuatan undangundang tersebut bertujuan untuk melindungi kepentingan masyarakat dan juga untuk mewujudkan tata tertib dalam kehidupan bermasyarakat.

Dilndonesia melalui sistem hukum nasional yang merupakan hukum yang berlaku dengan semua elemennya yang saling menunjang satu dengan yang lain dalam rangka mengantisipasi dan mengatasi permasalahan yang timbul dalam kehidupan bermasyarakat, berbangsa, dan bernegara didasarkan pada Pancasila dan UUD Negara Republik Indonesia Tahun 1945. Oleh karena itu, melalui sistem norma hukum Indonesia, maka norma-norma hukum yang berlaku berada dalam suatu sistem yang berlapis-lapis dan berjenjang-jenjang sekaligus berkelompok-kelompok, dimana suatu norma itu selalu berlaku, bersumber dan berdasar pada norma yang lebih tinggi dan norma yang lebih tinggi lagi, demikian seterusnya sampai pada suatu norma dasar negara (staatsfundamentalnorm) Republik Indonesia yaitu Pancasila. ${ }^{5}$

Sebagai konsekuensi adanya tata urutan (hierarki) perundang-undangan, sehingga setiapjenis undang-undang harus diperhatikan materi muatan atau norma hukum yang akan dituangkan dalam undang-undang. Setiapjenis

Purnadi Purbacaraka dan Soerjono Soekanto, Perihal Kaidah Hukum, (Bandung: Alumni, 1989), hlm. 8.

B. Arief Shidarta, "Pembentukan Hukum di Indonesia", Makalah disampaikan dalam Rapat Kerja Panitia Khusus DPR RI Rancangan Undang-Undang tentang Pembentukan Peraturan Perundang-undangan, Rapat Dengan Pendapat Umum dengan para Pakar, Rabu, 26 Januari 2011, hlm. 1 sebagaimana dikutip lagi oleh Bayu Dwi Anggono, Perkembangan Pembentukan Undang-undang di Indonesia, (Jakarta: Konstitusi Press, 2014), hlm. 1.

3 Jeremy Bentham, Teori Perundang-undangan, Prinsip-prinsip Hukum Perdata dan Hukum Pidana (The Theory of Legislation), diterjamahkan oleh Nurhadi, MA, (Bandung: Nusamedia, 2010), hlm. 17.

4 Ibid.

5 Maria Farida Indrati , Ilmu Perundang-undangan, Dasar-Dasar dan Pembentukannya, (Yogyakarta: Kanisius, 1998), hlm. 39. 
undang-undang mempunyai materi muatan atau norma hukum yang didasarkan pada peraturan perundang-undangan diatasnya dalam hal ini adalah UUDNRI Tahun 1945. Membentuk suatu undang-undang tentu saja membutuhkan rencana yang baik untuk menentukan kearah mana suatu undangundang tersebut dibentuk. Membentuk suatu undang-undang harus dilakukan berdasarkan asas pembentukan undang-undang yang meliputi kejelasan tujuan, kelembagaan atau pejabat yang tepat dan kesesuaian antara jenis, hirarkhi serta materi muatan yang dapat dilaksanakan dan didayagunakan serta hasil guna kejelasan rumusan dalam pasal-pasal. Begitu juga pembentukan undang-undang di Indonesia yang dibentuk oleh berbagai lembaga yang berbeda yang masing-masing mempunyai fungsi dan sekaligus materi muatan yang berbeda-beda sesuai dengan jenjangnya, sehingga tata susunan, fungsi dan materi muatan peraturan perundangundangan itu selalu membentuk hubungan fungsional antara peraturan yang satu dengan lainnya. ${ }^{6}$

Semua peraturan perundang-undangan termasuk undang-undang di Indonesia harus sesuai dengan konsep hierarki peraturan perundang-undangan sebagaimana dijelaskan dalam Undang-undang Nomor 12 Tahun 2011 tentang Pembentukan Peraturan Perundangundangan yang merupakan konsep dan paradigma dalam pembentukan peraturan perundang-undangan. Kehadiran konsep omnibus law yang merupakan paradigma baru hukum di Indonesia telah dikemukakan oleh Presiden Joko Widodo sebagai program pembangunan di bidang hukum pada masa periodenya. Alasan Presiden Joko Widodo menghendaki konsep omnibus law itu, dikarenakan adanya ribuan regulasi yang tersebar di berbagai lembaga tersebut membuat pembangunan terhambat. Oleh karena itu, untuk merampingkannya perlu dibuat payung hukum dengan undang-undang yang bercirikan omnibus law. Konsep Omnibus law tersebut dalam dunia hukum di Indonesia masih baru dan dalam bentuk undang-undang seperti apa yang akan dibuat. Di Indonesia, pembentukan undang-undang dengan konsep omnibus law ini telah menimbulkan pro dan kontra di kalangan masyarakat, bahkan perbedaan pendapat diantara ahli hukum.

Menurut Patrick, jika ditarik dalam konteks Indonesia adalah bahwa omnibus law menjadi problematik karena sangat sulit untuk disusun, membatasi kesempatan untuk mendebat dan mengawasi, menyulitkan proses konsultasi, serta pelaksanannya juga semakin sulit dan semakin menambah kompleksitas dari sebuah hukum itu sendiri. ${ }^{7}$ Sejalan dengan pendapat Patrick, konsep omnibus law ini berbeda dengan konsep hukum yang sudah ada di Indonesia. Konsep omnibus law berbeda dengan konsep atau model hukum yang selama ini sudah ada seperti Undang-undang Pokok, Undang-undang Organik, Undang-undang Payung, kodifikasi atau unifikasi hukum, dan juga kompilasi hukum.Proses pembentukan Undang-undang juga memerlukan waktu yang panjang dan juga yang penting norma hukum yang dimuat tidak akan menimbulkan permasalahan.Makna dan sifat hukum dalam konsep omnibus law berbeda dengan sifat dan

Lihat Undang-Undang Nomor 21 Tahun 2001 Tentang Otonomi Khusus di Papua.

http://kanal24.co.id/read/patrick-keyzer-omnibus-law-menambah-kompleksitas-hukum-indonesia. (diunduh, Rabu, 6 Februari, 2020). 
konsep norma hukum dalam undang-undang yang sudah ada. Penulis mencoba menelusuri konsep omnibus law yang menjadi khasanah baru dan juga paradigma baru hukum di Indonesia. Selain itu, norma hukum seperti apakah yang akan dimuat menurut sistem peraturan perundang-undangan Indonesia.

\section{B. Metode Penelitian}

Metode penelitian yang digunakan adalah penelitian deskriptif dengan pendekatan penelitian yang digunakan adalah penelitian diskriptif normatif atau atau dapat juga dikatakan penelitian yuridis normatif. Menurut Philipus M. Hadjon, penelitian yuridis normatif atau penelitian hukum normatif merupakan penelitian yang ditujukan untuk menemukan dan merumuskan argumentasi hukum melalui analisis terhadap pokok permasalahan. ${ }^{8}$ Dalam pendekatan hukum normatif, hukum dikonsepkan sebagai apa yang tertulis dalam perundang-undangan (law in book) atau hukum dikonsepkan sebagai kaidah atau norma yang merupakan patokan berperilaku manusia yang pantas. ${ }^{9}$ Menurut Lili Rasjidi: "bahwa metode penelitian hukum yang original adalah metode penelitian hukum normatif". ${ }^{10}$ Penelitian hukum normatif dapat dipergunakan untuk menerangkan, memperkuat, menguji atau menolak suatu teori dari penelitian-penelitian yang sudah ada. Oleh karena itu, "penelitian hukum (secara) normatif, yaitu penelitian terhadap kaidah hukum itu sendiri",, ${ }^{11}$ dalam pembentukan perundang-undangan yang bercirikan konsep omnibus law. Begitu juga dilihat dari sudut penerapannya, penelitian ini merupakan penelitian berfokus masalah, yaitu permasalahan yang diteliti didasarkan pada teori atau dilihat kaitannya antara teori dan praktek. ${ }^{12}$ Masalah dalam hal ini menganalisis secara yuridis permasalahan norma hukum dalam pembentukan undangundang menurut perspetif omnibus law di Indonesia yang berarti apa dan bagaimana konsep undang-undang dalam perspektif omnibus law di Indonesia. Sumber data berasal dari peraturan perundang-undangan, artikel, buku, dan internet/website.

\section{Pembahasan}

\section{Perkembangan Paradigma Omnibus Law di Indonesia}

Munculnya isu omnibus law dalam dunia ilmu hukum di Indonesia telah menambah khasanah baru dan paradigma baru dalam ilmu pengetahuan di bidang hukum. Banyak pihak yang mempertanyakan istilah omnibus law yang dikemukakan oleh Presiden Joko Widodo,karena khasanah ilmu pengetahuan hukum di Indonesia hanya mengenal adanya Undang-undang Pokok seperti Undang-

\footnotetext{
Philipus M. Hadjon dan Tatiek Sri djamiati, Argumentasi Hukum (Yogyakarta: Gadjah Mada Unversity press, 2005), hlm 3.

9 Amiruddin dan Zainal Asikin, Pengantar Metode Penelitian Hukum, (Jakarta: Raja Grafindo Persada, 2006), hlm. 118.

10 Lili Rasjidi dan Liza Sonia Rasjidi, Monograf: Filsafat Ilmu, Metode Penelitian, Dan Karya Tulis Ilmiah Hukum, (Bandung, 2009), tanpa halaman.

11 Kuntana Magnar, Hubungan Dewan Perwakilan Rakyat (DPR) Dengan Presiden Setelah Perubahan UndangUndang Dasar (UUD) 1945: Pencarian Bentuk dan Isi, Disertasi, Universitas Padjadjaran (Bandung, 2006), hlm. 42.

12 Soerjono Soekanto dan Sri Mamudji, Penelitian Hukum Normative -Suatu Tinjauan Singkat, (Jakarta: Raja Grafindo Persada, 1994), hlm. 5.
} 
Undang Pokok Agraria (Undang-Undang Nomor 5 Tahun 1960), Undang-undang Payung (Umbrella Act) seperti Undangundang Nomor 32 Tahun 2009 tentang Perlindungan dan Pengelolaan Lingkungan Hidup, juga dikenal adanya kodifikasi hukum yang menghimpun beberapa hukum dalam permasalahan atau objek hukum yang sama seperti Kitab Undang-undang Hukum Perdata, Kitab Undang-undang Hukum Pidana, Kitab Undang-undang Hukum Acara Pidana, Kitab Undang-undang Hukum Dagang, dan juga adanya Kompilasi Hukum Islam.

Berbagai literatur menunjukkan istilah omnibus law yang dimaksud merupakan suatu Undang-Undang (UU) yang dibuat untuk menyasar satu isu besar yang mungkin dapat mencabut atau mengubah beberapa Undang-undang sekaligus, sehingga menjadi lebih sederhana. ${ }^{13}$ Menurut M. Mahfud MD, pada tahun 1830 di kota Paris, Perancis untuk pertama kalinya hadir sebuah bus yang bisa mengangkut barang dan orang sekaligus ke satu tujuan yang sama. Konon, saat itu belum ada bus yang dipakai untuk mengangkut orang dan barang sekaligus alias dibawa secara terpisah-pisah. Bus itu disebut dengan nama omnibus. Selanjutnya nama Omnibus dipakai oleh negara-negara Amerika Latin untuk sebuah istilah hukum yang bisa mengatur banyak hal lewat sebuah Undang-undang. Istilah omnibus law pun dikenal sebagai hukum yang dipakai untuk memuat banyak hal namun lebih efisien. ${ }^{14}$

Patrick Keyzer menyebutnya Omnibus is a Latin word that means "all" or "for everything", sehingga an omnibus law is a law that covers a number of diverse or unrelated topics. ${ }^{15}$ Omnibus law juga dikenal dengan omnibus bill. Black's Law Dictionary merumuskan kata Omnibus yaitu, relating to or dealing with numerous objects or items at once, including many things or having various purposes. ${ }^{16}$ Pendapat dari segi hukum, kata omnibus lazimnya disandingkan dengan kata law atau bill yang berarti suatu peraturan yang dibuat berdasarkan hasil kompilasi beberapa aturan dengan substansi dan tingkatannya berbeda. Menurut Audrey O. Brien, omnibus law adalah suatu rancangan undang-undang (bill) yang mencakup lebih dari satu aspek yang digabung menjadi satu undang-undang. Sementara bagi Barbara Sinclair, omnibus bill merupakan proses pembuatan peraturan yang bersifat kompleks dan penyelesaiannya memakan waktu lama karena mengandung banyak materi meskipun subjek, isu, dan programnya tidak selalu terkait. ${ }^{17}$ Dalam kamus hukum Merriam-Webster bahwa istilah Omnibus Law bersumber dari Omnibus Bill, yakni Undang-undang yang mencakup berbagai isu atau topik. Melalui Omnibus Law dapat merevisi banyak aturan sekaligus. ${ }^{18}$

13 https://www.wartaekonomi.co.id/read260634/apa-itu-omnibus-law, (diunduh, Rabu, 6 Februari 2020).

14 Demikian disampaikan oleh Menko Polhukam M. Mahfud MD dalam sambutannya pada acara Law \& Regulation Outlook 2020 di Hotel Shangri-La, Jakarta Pusat, (Rabu 22 Januari 2020).

15 Patrick Keyzer, "The Indonesian Omnibus Law: Opportunities and Challenges", Kuliah Umum, Universitas Brawijaya, (Malang, 29 January 2020).

16 Black's Law Dictionary, West Publishing Wo, (2004), hlm. 1121.

17 https://business-law.binus.ac.id/2019/10/03/memahami-gagasan-omnibus-law/, (diunduh, Senin, 3 February 2020).

18 https://nasional.sindonews.com/read/1509229/16/serikat-pekerjatolak-omnibus-law-1580140561, (diunduh, Senin, 3 Februari 2020). 
Implementasi konsep omnibus law dalam peraturan perundang-undangan ini lebih mengarah pada tradisi Anglo-Saxon yang bercirikan sistem Common Law. Beberapa negara seperti Amerika, Kanada, dan Irlandia disebutnya telah menggunakan pendekatan omnibus law atau omnibus bill. Konsep ini sering digunakan oleh Amerika Serikat dalam membuat regulasi. Regulasi dalam konsep ini adalah membuat satu Undang-undang baru untuk mengamandemen beberapa Undangundang sekaligus. ${ }^{19}$ Pada tahun 1888, praktik omnibus law muncul pertama kali di Amerika Serikat. Sebutan yang digunakan adalah omnibus bill. Penyebabnya adalah perjanjian privat terkait pemisahan dua rel kereta api di Amerika. Pada tahun 1967 rancangan metode ini menjadi populer. Saat itu Menteri Hukum Amerika Serikat, Pierre Trudeau mengenalkan Criminal Law Amendement Bill. Isinya mengubah undang-undang hukum pidana dan mencakup banyak isu. ${ }^{20}$

Dengan demikian, dapat dikatakan omnibus law merupakan metode atau konsep pembuatan peraturan yang menggabungkan beberapa aturan yang substansi pengaturannya berbeda, menjadi suatu peraturan besar yang berfungsi sebagai payung hukum. Apabila peraturan itu diundangkan, makakonsekuensinya mencabut beberapa aturan hasil penggabungan dan substansinya selanjutnya dinyatakan tidak berlaku, baik untuk sebagian maupun secara keseluruhan. ${ }^{21}$ Dalam konteks undang-undang dengan metode omnibus law dapat dimaknai sebagai penyelesaian berbagai pengaturan dalam peraturan perundang-undangan ke dalam satu undang-undang.

Pemerintah bersama DPR mencoba melakukan terobosan di bidang hukum dengan mengadopsi konsep omnibus law yang sudah dipraktekkan di Amerika Serikat dan di beberapa negara lainnya yang menganut sistem hukum Anglo Saxon. Pemerintah bersama DPR beranggapan bahwa salah satu keunggulan metode omnibus law adalah kepraktisan untuk mengoreksi banyak regulasi bermasalah. Meningkatkan kecepatan dalam penyusunan undang-undang, sebab dengan menyusun sebuah undang-undang metode omnibus law sekaligus mengoreksi undangundang bermasalah yang sedang berlaku. Pendekatan omnibus law juga bisa menjadi solusi atas tumpang tindih regulasi di Indonesia. Baik yang dalam hubungan hirarki sejajar horizontal maupun vertikal. Sebenarnya penyusunan omnibus law berbiaya mahal dan tidak sederhana karena substansinya pasti multisektor dan membutuhkan waktu yang lama.

Anggapan, bahwa konsep omnibus law menjadi salah satu jalan keluar yang bisa diambil oleh pemerintah dalam rangka meningkatkan kemajuan bangsa melalui bidang hukum. Persoalan adanya konsep omnibus law sebagai jalan keluarnya karena ada persoalan konflik antara penyelenggara pemerintahan dalam melakukan inovasi atau kebijakan yang kemudian berbenturan dengan peraturan perundang-undangan. Banyaknya peraturan perundang-undangan berbelit inilah yang menyebabkan perkembangan 
perekonomian negara belum dapat dikatakan membaik, akan tetapi, omnibus law harus dibuat dalam tingkatan Undang-undang. Anggapan bahwa penggunaan konsep omnibus law sepertinya mampu menjawab persoalan tumpang tindih aturan perundangundangan di Indonesia.

Menurut anggapan pemerintah ada tiga manfaat penerapan Omnibus Law. Pertama, menghilangkan tumpang tindih antar peraturan perundang-undangan. Kedua, efisiensi proses perubahan atau pencabutan peraturan perundang-undangan. Ketiga, menghilangkan ego sektoral yang terkandung dalam berbagai peraturan perundangundangan. ${ }^{22}$ Konsep Omnibus law bisa digunakan di Indonesia untuk penyeragaman kebijakan pusat dan daerah dalam menunjang iklim investasi. Konsep omnibus law juga bisa menjadi cara singkat sebagai solusi peraturan perundang-undangan yang saling berbenturan, baik secara vertikal maupun horizontal.

\section{Norma Hukum dalam Konsep Hukum Nasional Dengan Konsep Omnibus Law}

Hukum nasional suatu negara merupakan gambaran dasar mengenai tatanan hukum nasional yang dianggap sesuai dengan kondisi masyarakat yang bersangkutan ${ }^{23}$, berarti norma hukum mencerminkan hukum nasional. Norma hukum dalam perundang-undangan di Indonesia tidak menyimpang dari sistem hukum nasional, karena sistem hukum nasional merupakan hukum yang berlaku di Indonesia dengan semua elemennya yang saling menunjang satu denganyang lain dalam rangka mengantisipasi dan mengatasi permasalahan yang timbul dalam kehidupan bermasyarakat, berbangsa, dan bernegarayang berdasarkan Pancasila dan Undang-Undang Dasar Negara RepublikIndonesia Tahun 1945. ${ }^{24}$

Penjelasan umum dalam alinea kedua Undang-undang Nomor 15 Tahun 2019 tentang Perubahan Atas Undang-undang Nomor 12 Tahun 2011 tentang Pembentukan Peraturan Perundang-undangan, menunjukkan karakter undang-undang (hukum) yang terbentuk di Indonesia yang bercirikan pada budaya masyarakat hukum Indonesia dengan Pancasila sebagai dasar filosofinya. Oleh karena hukum dibuat oleh penguasa, keberadaan hukum tidak dapat dilepaskan dari pertimbanganpertimbangan politik, ekonomi, sosial dan budaya, tetapi faktor-faktor itu tidak dapat dinafikkan begitu juga karena pertimbangan itu tidak boleh menyisihkan esensi hukum. ${ }^{25}$ Esensi hukum yaitu hakikat hukum yang justru menjadi dasar pijakan dalam pembuatan undang-undang maupun pengambilan putusan dalam proses peradilan dan tindakan eksekutif. ${ }^{26}$ Undang-undang yang dibuat harus mencerminkan hukum nasional itu sendiri yang tercerminkan dalam sistem hukum nasional yang berdasarkan Pancasila

\footnotetext{
22 https://economy.okezone.com/read/2020/01/22/320/2156470/omnibus-law-itu-apa-ini-jawabannya, (diunduh, Senin, 3 February 2020).

23 Wawan Muhwan Hariri, Pengantar Ilmu Hukum, (Bandung: Pustaka Setia, 2012), hlm. 170.

24 Alinea Kedua Penjelasan umum Undang-undang Nomor 15 Tahun 2019 tentang Perubahan Atas Undang-undang Nomor 12 Tahun 2011 tentang Pembentukan Peraturan Perundang-undangan.

25 Peter Mahmud Marzuki, Pengantar Ilmu Hukum, (Jakarta: Pranada Media Group, 2008), hlm. 97.

26 Ibid, hlm. 98.
} 
dan UUD 1945, yaitu melalui hirarki peraturan perundang-undangan.

Undang-undang yang dibuat tentu saja mengatur norma hukum tentang satu objek hukum atau hal tertentu bukan berbagai objek hukum atau hal sekaligus. Dalam tata urutan peraturan perundang-undangan, maka Undang-undang itu sendiri dalam tingkatan hirarki peraturan perundangundangan menempati tingkatan setelah Ketetapan MPR dan UUD 1945. Oleh karena itu, Undang-undang yang dibuat tidak membatalkan Undang-undang yang sederajat karena Undang-undang adalah setingkat dan mengatur hal satupersoalan. Apabila Undangundang yang baru dibuat untuk membatalkan Undang-undang yang ada, tentu saja Undangundang tersebut memuat norma untuk membatalkan Undang-undang yang ada dan Undang-undang yang membatalkan adalah Undang-undang yang mengatur persoalan yang sama dengan undang-undang yang dibatalkan.

Pemberlakuan norma hukum itu sifatnya harus vertikal karena Undang-undang tidak boleh bertentangan dengan Undangundang di atasnya dalam hal ini UUD 1945 sesuai dengan hirarki teori perundangundangan,sehingga pemberlakuan norma hukum itu tidak bersifat horizontal. Dikatakan oleh Bagir Manan, bahwa dalam hal peraturan perundang-undangan yang sederajat bertentangan dengan peraturan perundangundangan sederajat lainnya, maka berlaku peraturan perundang-undangan yang terbaru dan peraturan perundang-undangan lama dianggap telah dikesampingkan (lex posterior derogate priori). ${ }^{27}$ Begitu juga, dalam hal peraturan perundang-undangan yang lebih tinggi tingkatnya bertentangan dengan peraturan perundang-undangan yang lebih rendah, maka berlaku peraturan perundangundangan yang lebih tinggi tingkatannya. ${ }^{28}$ Selanjutnya, dalam hal peraturan perundangundangan yang mengatur bidang-bidang yang merupakan kekhususan dari bidangbidang umum yang diatur oleh peraturan yang sederajat, maka berlaku peraturan perundang-undangan yang mengatur bidang khusus tersebut (lex specialis derogat lex generali). ${ }^{29}$

Selain itu, tentu saja ditekankan pentingnya Undang-undang dibuat dengan baik dan benar, maka sangat terkait dengan unsur yuridis, sosiologis dan filosofis. Sebagaimana dikemukakan oleh Bagir Manan, sebab setiap pembuat peraturan perundang-undangan berharap agar kaidah yang tercantum dalam perundang-undangan itu adalah sah secara hukum (legal validity) dan berlaku efektif karena dapat atau akan diterima masyarakat secara wajar dan berlaku untuk waktu yang panjang. ${ }^{30}$ Kaitannya dengan unsur yuridis yang berarti setiap kaidah hukum harus berdasarkan kaidah yang lebih tinggi tingkatannya, kaidah hukum harus memenuhi syarat-syarat pembentukannya, dan kaidah hukum itu mengikat kalau menunjukkan hubungan keharusan (hubungan memaksa) antara suatu kondisi dan akibatnya. ${ }^{31}$ Unsur

\footnotetext{
Bagir Manan, Dasar-Dasar Perundang-undangan Indonesia, (Jakarta: Ind-Hill-Co, 1992), hlm. 22.

Ibid.

Ibid. hlm. 23.

Ibid, hlm. 14.

Purnadi Purbacaraka dan Soerjono Soekanto, Op.cit, hlm. 88.
} 
sosiologis diharapkan peraturan perundangundangan yang dibuat akan diterima oleh masyarakat secara wajar bahkan spontan, peraturan perundang-undangan yang diterima secara wajar akan mempunyai daya berlaku efektif dan tidak begitu banyak memerlukan pengerahan institusional untuk melaksanakannya. ${ }^{32}$ Unsur filosofis menunjukkan bahwa setiap masyarakat selalu mempunyai rechtsidee yaitu apa yang mereka harapkan dari hukum, misalnya untuk menjamin keadilan, ketertiban, kesejahteraan dan sebagainya. Cita hukum atau rechtsidee tersebut tumbuh dari sistem nilai mereka mengenai baik dan buruk, pandangan mereka mengenai hubungan individu dan kemasyarakatan, tentang kebendaan dan lain-lain. ${ }^{33}$

Undang-undang dengan konsep omnibus law berkaitan atau berurusan dengan berbagai objek atau hal sekaligus, dan memiliki berbagai tujuan. Undang-undang dengan konsep omnibus law ini memang dikenal sejak 1840, yang merupakan aturan yang bersifat menyeluruh dan komprehensif, tidak terikat pada satu rezim pengaturan saja. Oleh karena itu, Undang-undang dengan konsep omnibus law sangat tepat diberlakukan pada masa itu, tetapi pada zaman sekarang dengan persoalan kehidupan yang kompleks, apa mungkin akan diatur dalam satu undang-undang yang bersifat menyeluruh dengan berbagai objek hukum dan menampung semua persoalan kehidupan yang kompleks ini.

Pasal 10 ayat (1) Undang-undang Nomor 12 Tahun 2011 tentang Pembentukan Peraturan Perundang-undangan sebagaimana diubah dengan Undang-undang Nomor 15 Tahun 2019 menjelaskan materi muatan yang harus diatur dengan Undang-undang yang berisi (a) pengaturan lebih lanjut mengenai ketentuan Undang-Undang Dasar Negara Republik IndonesiaTahun 1945; (b) perintah suatu Undang-Undang untuk diaturdengan Undang-Undang; (c) pengesahan perjanjian internasional tertentu; (d) tindak lanjut atas putusan Mahkamah Konstitusi;dan/atau (e) pemenuhan kebutuhan hukum dalam masyarakat. Berdasarkan Pasal 10 ayat (1) tersebut menunjukkan bahwa norma hukum sebagai materi muatan yang berupa pasalpasalnya juga tidak mencoba-coba untuk mengubah norma hukum yang sudah ada di dalam undang-undang sebelumnya (existing regulation). Hal ini karena ada banyak norma hukum yang mendukung eksistensi norma/ kaidah hukum yang sudah berlaku. Sebagai contoh norma hukum yang berupa norma definisi dan norma penilaian (asas-asas). Begitu juga perlu diperhatikan definisi yang ada di dalam undang-undang dengan konsep omnibus law jangan sampai mengubah secara prinsipiil untuk suatu konsep kunci, karena konsep itu telah didefinisikan ciri-cirinya di dalam undang-undang sebelumnya.

Asas-asas penting dalam undang-undang sebelumnya tidak ikut berubah karena strategi jangka pendek dan tujuan pragmatis dalam undang-undang dengan konsep omnibus law. Hal ini, perlu diperhatikan dua klasifikasi asas, yakni supra-principle dan fundamental principles, kedua asas hukum tersebut harus dijaga secara konsisten antara undangundang dengan konsep omnibus law dan

32 Bagir Manan, Op.cit, hlm. 16.

33 Ibid, hlm. 17. 
undang-undang yang sudah ada sebelumnya. Sebagai contoh apabila ingin mengutak atik atau mencoba-coba kaidah hukum, maka kaidah hukum yang paling aman untuk dicoba diubah adalah dalam lapangan hukum administrasi yaitu mengenai penyederhanaan perizinan yang berupa norma atau kaidah kewenangan dalam hukum administrasi. Pendapat demikian tidak lain adalah dalam rangka menjaga keutuhan sistem hukum nasional. Hal ini, karena sistem hukum sebagai konstruksi (teoritis) yang di dalamnya pelbagai norma/kaidah hukum dipikirkan dalam suatu hubungan logis-konsisten menjadi satu kesatuan tertentu. ${ }^{34}$

Penyusunan Undang-undang dengan konsep atau metode omnibus law, dengan mengatur banyak hal dan berbagai objek hukum, maka memerlukan banyak aturan atau norma hukum yang dimuat, sehingga norma atau kaidah hukum apa saja yang akan dijadikan satu rancangan undang-undang yang baru. Rancangan Undang-undang dengan konsep omnibus law tersebut semestinya memerlukan proses waktu yang lama, karena harus mengikuti proses pembuatan peraturan perundang-undangan sebagai ditetapkan dalam Undang-undang Nomor 12 Tahun 2011 tentang Pembentukan Peraturan Perundang-undangan sebagaimana diubah dengan Undang-undang Nomor 15 Tahun 2019. Pembentukan Undang-undang dengan konsep atau metode omnibus law yang sekarang sedang disusun oleh pemerintah bersama DPR yang rancangannya sekarang sudah masuk ke DPR hanya memerlukan beberapa bulan sudah jadi RUU. Sesuai dengan Pasal 20 Undang-Undang Nomor 12 Tahun 2011 tentang Pembentukan Peraturan Perundang-undangan sebagaimana diubah dengan Undang-undang Nomor 15 Tahun 2019 yaitu, ayat (1) Penyusunan Prolegnas dilaksanakan oleh DPR dan Pemerintah, (2) Prolegnas ditetapkan untuk jangka menengah dan tahunan berdasarkan skala prioritas pembentukan Rancangan Undang-Undang, (3) Penyusunan dan penetapan Prolegnas jangkah menengah dilakukan pada awal masa keanggotaanDPR sebagai Prolegnas untuk jangka waktu 5 (lima)tahun, (4) Prolegnas jangka menengah dapat dievaluasi setiap akhir tahun bersamaan dengan penyusunan dan penetapan Prolegnas prioritas tahunan, (5) Penyusunan dan penetapan Prolegnas prioritas tahunan sebagai pelaksanaan Prolegnas jangka menengah dilakukan setiap tahun sebelum penetapan Rancangan UndangUndang tentang Anggaran Pendapatan dan Belanja Negara.

Menurut Jimly Asshiiddiqie, prinsip umum yang perlu diperhatikan oleh perancang undang-undang, adalah garis besar kebijakan yang akan dituangkan dalam undangundang melalui outline building yang bersifat menyeluruh dan komprehensif; produk undang-undang harus sejelas dan seberguna mungkin (as clear and useful as possible); memperhatikan kepentingan pihak yang akan diatur atau yang akan melaksanakan undangundang (the person or subject who will administer the (aw); mengacu pada kebutuhan atau memenuhi tujuan telah dirumuskan (functional); efisien atau menghindari perujukan silang (cross reference) ${ }^{35}$. Didalam 
pembentukan peraturan perundangundangan harus ada persiapan penyusunan secara akademik melalui naskah akademik, karena naskah akademik adalah naskah hasil penelitian atau pengkajian hukum dan hasil penelitian lainnya terhadap suatu masalah tertentu yang dapat dipertanggungjawabkan secara ilmiah mengenai pengaturan masalah tersebut dalam suatu Rancangan UndangUndang, Rancangan Peraturan Daerah Provinsi, atau Rancangan Peraturan Daerah Kabupaten/Kota sebagai solusi terhadap permasalahan dan kebutuhan hukum masyarakat. $^{36}$ Dengan demikian, dalam proses pembentukan peraturan perundangundangan diketahui ada 5 (lima) tahapan, mulai dari persiapan masuk di Prolegnas terlebih dahulu satu tahun sebelumnya kemudian di tahun berikutnya mulai dilakukan pembahasan. Semakin banyak topik yang dibahas, mestinya memerlukan waktu yang lama. Selanjutnya dalam proses penelitian harus ada diskusi, forum group disccusion, dan seterusnya dengan menghadirkan semua stakeholder. Mereka (stakeholder) diberikan kesempatan untuk bersuara dan memberikan aspirasi untuk memastikan bahwa ini untuk kepenting rakyat bukan untuk kepentingan yang lain

Apabila Undang-undang dengan konsep omnibus law yang sekarang sedang dibahas dengan waktu yang cepat, maka apakah Undang-undang tersebut kemudian untuk merepresentasikan kepentingan dari setiap kelompok yang ada, hal inilah yang harus diperbaiki agar Undang-undang dibuat untuk kepentingan bangsa dan negara. Apabila
Undang-undang dengan konsep omnibus law dibentuk dalam waktu yang singkat, maka seharusnya Undang-undang tersebut yang terbentuk untuk keperluan jangka pendek dan sangat pragmatis.

\section{Konsep Omnibus Law Dengan Model Hukum Indonesia}

Sebagaimana dijelaskan dalam poin dua di atas tentang norma hukum yang seharusnya dalam paradigma hukum nasional, demikian juga undang-undang dengan konsep omnibus law berbeda dengan model hukum yang dikenal di Indonesia. Model hukum Indonesia yang dikenal sekarang ini adalah seperti undang-undang pokok, undangundang organik, undang-undang payung dan kodifikasi atau unifikasi hukum serta kompilasi hukum. Apabila omnibus law yang dimaksud merupakan suatu Undang-undang yang dibuat untuk menyatukan isu besar atau menampung berbagai aspek hukum yang mungkin dapat mencabut atau mengubah beberapa undangundang sekaligus sehingga menjadi lebih sederhana, maka terdapat perbedaan dengan model hukum yang dikenal di Indonesia. Sebagai contoh misalnya undang-undang pokok yang dimaksud disini adalah undangundang yang menjadi pokok atau asas dalam pengaturan sesuatu (masih memerlukan peraturan pelaksanaan). ${ }^{37}$ Salah satu contoh adalah Undang-Undang Pokok Agraria yang secara resmi bernama Undang-Undang Nomor 5 Tahun 1960 tentang Peraturan Dasar Pokok-Pokok Agraria. Undang-undang Pokok Agraria ini adalah undang-undang yang mengatur tentang dasar-dasar dan ketentuan

\footnotetext{
36 Pasal 1 angka 11 Undang-undang Nomor 12 Tahun 2011 tentang Pembentukan Peraturan Perundang-undangan Sebagaimana diubah dengan Undang-undang Nomor 15 Tahun 2019.

37 https://id.wiktionary.org/wiki/undang-undang_pokok, (diunduh, Senin, 10 Februari 2020).
} 
penguasaan, pemilikan, penggunaan dan pemanfaatan sumber daya agraria nasional di Indonesia. Cakupan undang-undang tersebut mengatur tentang dasar-dasar dan ketentuanketentuan pokok, hak-hak atas tanah, air dan ruang angkasa serta pendaftaran tanah, ketentuan-ketentuan pidana dan ketentuan peralihan. Norma hukum yang terkandung dalam undang-undang pokok (UndangUndang Pokok Agraria) mengatur agraria secara administratif, dan norma hukum lainnya yang lebih spesifik diatur lebih lanjut dengan undang-undang lain, sehingga masih memerlukan norma pengaturan lebih lanjut baik melalui undang-undang maupun peraturan lainnya.

Selain undang-undang pokok juga dikenal adanya undang-undang organik yaitu undang-undang yang mengatur materi atau persoalan yang digariskan oleh ketentuanketentuan hukum yang menjadi dasarnya (baik UUD 45, maupun TAP MPR). Soehino menyebutkan bahwa undang-undang organik adalah undang-undangyang dibentuk untuk melaksanakan secara langsung perintah dariketentuan Undang-Undang Dasar. ${ }^{38}$ Abdul Gani Abdullah juga mengartikan undangundang organik sebagai undang-undang yang secara tegas melaksanakan UndangUndang Dasar Negara Republik Indonesia Tahun $1945 .{ }^{39}$ Salah satu contohnya adalah Undang-undang tentang Anggaran Belanja dan Pendapatan Negara (APBN) adalah undang-undang organik yang melaksanakan ketentuan Pasal 23 ayat (1) UUD 1945. Jadi, Undang-undang organik adalah undangundang yang dibentuk untuk melaksanakan perintah Undang-Undang Dasar 1945 yang disebutkan secara tegas, dan juga mengatur segala ketentuan yang berhubungan dengan keorganisasian negara.

Ada sebagian pendapat yang menyatakan bahwa undang-undang dengan konsep omnibus law bisa mengarah sebagai undangundang payung (Umbrella Act) karena mengatur secara menyeluruh dan kemudian mempunyai kekuatan terhadap aturan yang lain. Apabila dilihat dari asal usul kedua model Undang-undang tersebut memang berasal dari sistem hukum Anglo Saxon, akan tetapi mencoba mengetahui lebih rinci tentang Undang-undang Payung (Umbrella Act) yang dimaksud. Undang-undang Payung mirip atau hampir sama dengan undang-undang pokok, tetapi undang-undang pokok berasal dari sistem hukum Eropa Kontinental sedangkan undang-undang payung berasal dari sistem hukum Anglo Saxon. Istilah Undang-undang Payung ini diharapkan menjadi atau sebagai sandaran dan batu uji yang dapat memayungi Undang-undang lainnya yang berkaitan secara teknis denganUndang-undang tersebut.

Undang-undang payung memberikan arahan dan pedoman dari setiap persoalan satu isu hukum, sehingga argumentasi dengan adanya undang-undang payung maka dapat dibangun keserasian atau keselarasan berbagai peraturan perundang-undangan

Soehino, Hukum Tatanegara, Teknik Perundang-undangan, (Yogyakarta, Liberty, 1990). hlm. 18.

39 Undang-undang tentang Pembentukan Peraturan Perundang-undnagan merupakan undang-undang organik, karena melaksanakan secara tegas perintah Undang-Undang Dasar Negara Republik Indonesia Tahun 1945 Pasal 22A yang menyatakan bahwa ketentuan mengenai tata cara pembentukan undang-undang diatur dengan undang-undang. Abdul Gani Abdullah, Pengantar Memahami Undang-Undang Jurnal Legislasi, Volume I No. 2, (September 2004), hlm. 1. 
sehinggga peraturan tidak menjadi kacau, saling bertentangan antara satu Undangundang dengan Undang-undang lain, tidak jalan sendiri dan tidak mengabaikan kepastian hukum kepada masyarakat. ${ }^{40}$ Apabila diambilkan sebagai contoh mungkin yang lebih tepat adalah Undang-undang Nomor 32 Tahun 2009 tentang Perlindungan dan Pengelolaan Lingkungan Hidup, karena seluruh undang-undang yang berkaitan dengan sumber daya alam dan lingkungan hidup harus memperhatikan ketentuan didalam Undang-undang Nomor 32 Tahun 2009. Undang-undang yang berkaitan dengan sumber daya alam yang berpayung terhadap Undang-undang Nomor 32 Tahun 2009 adalah Undang-undang Minerba, Undang-undang Kehutanan, Undang-undang Kesehatan, Undang-undang Perkebunan, Undang-undang Sumber Daya Air, Undang-undang Pesisir dan Pulau-Pulau Kecil dan sejenisnya. Di sini adanya sinkronisasi maupun keselarasan antara satu Undang-Undang dengan UndangUndang lain menjadi baik, sehingga akan dapat memberikan kepastian hukum kepada masyarakat. Dengan demikian, dapat dikatakan bahwa Undang-undang dengan konsep omnibus law tidak dapat disamakan dengan Undang-undang Payung, karena norma hukum yang berlaku berbeda.

Selanjutnya, undang-undang dengan konsep omnibus law berbeda apabila disamakan dengan model hukum yang dikenal di Indonesia lainnya yaitu model penyatuan atau kumpulanhukum dalam satu buku atau kitab yang kemudian dikenal dengan kodifikasi dan unifikasi, serta kompilasi hukum. Kodifikasi Undang-undang yang dikenal di Indonesia adalah kumpulan undang-undang dalam objek hukum yang sama yang dijadikan satu buku atau kitab yang kemudian dikenal dengan Kitab Undang-Undang Hukum, misalnya Kitab Undang-undang Hukum Pidana, Kitab Undang-undang Hukum Acara Pidana, Kitab Undang-undang Hukum Perdata dan Kitab Undang-undang Hukum Dagang, dan dikenal juga dengan unifikasi hukum, bahkan dalam hukum Islam dikenal dengan Kompilasi Hukum Islam.

Dengan demikian, Undang-undang dengan metode omnibus law berbeda dengan konsep kodifikasi dan penyatuan hukum di Indonesia. Kodifikasi merupakan pembukuan hukum dalam suatu himpunan undang-undang dalam materi yang sama. Kodifikasi ini berasal dari sistem hukum civil law yang dianut oleh negara-negara Eropa Kontinental yang kemudian dibawa ke Indonesia. Selanjutnya, kodifikasi yang menjadi ciri dari system civil law merupakan sistem hukum yang diilhami dari hukum Romawi dengan cara ditulis dalam suatu kumpulan, dikodifikasi, dan tidak dibuat oleh hakim. ${ }^{41}$ Kodifikasi merupakan suatu bentuk hukum yang dibuat secara tertulis, dimana pembuatnya (legislative) memberikan suatu bentuk yuridiksi khusus yang berisikan rumusan asas-asas yang dibuat secara tertulis sebagai suatu standar operasi berlakunya ketentuan dalam kodifikasi (exclusive operation/exclusive verwerking). ${ }^{42}$

\footnotetext{
40 https://jambi-independent.co.id/read/2016/12/20/11955/polemik-undangundang-payung/,(diunduh, Senin, 10 Februari 2020).

41 Charles Arnold Baker, the Companion to British History, s.v. Civilian, (London: Rotledge, 2001), hlm. 308.

42 Tim Pengajar Hukum Pidana UI, Position Paper (RKUHP Kodifikasi atau Kompilasi), (Jakarta: Bidang Studi Hukum Pidana UI, 2014), hlm. 4.
} 
Pembentuk Undang-undang tidak merumuskan norma hukum dalam kodifikasi untuk menyampingkan atau membatalkan Undang-undang yang sudah ada, karena tujuan kodifikasi adalah untuk mengatasi tidak adanya kepastian hukum dan kesatuan hukum. ${ }^{43}$ Dedi Soemardi juga menjelaskan kodifikasi bertujuan untuk mencapai kepastian hukum, sehingga hukum-hukum sejenis dihimpun secara sistematis dalam sebuah kitab. Sistem hukum yang baik harus mencerminkan suatu hubungan timbal balik yang serasi, baik antara bagian-bagiannya secara individual maupun hubungannya secara keseluruhan, berdasarkan kekuatan pemikiran. ${ }^{44}$ Pendapat CST Kansil yang dikutip oleh Institute for Criminal Justice Reform memberikan pendapat tentang tujuan dari kodifikasi hukum tertulis memiliki tiga tujuan: pertama, memperoleh kepastian hukum di mana hukum tersebut sungguh-sungguh telah tertulis dalam satu kitab undang-undang; kedua, penyederhanaan hukum, sehingga memudahkan masyarakat dalam memperoleh atau memiliki dan mempelajarinya; dan ketiga, kesatuan hukum, sehingga dapat mencegah kesimpangsiuran terhadap pengertian hukum yang bersangkutan, kemungkinan penyelewengan dalam pelaksanaannya, dan keadaan berlarut-larut dari masyarakat yang buta hukum. ${ }^{45}$

Di Indonesia, problematika kodifikasi tentu tidak bisa lepas dari arah politik hukum secara umum dan khususnya terhadap pembangunan hukum sehubungan dengan karakteristik produk undang-undang. Sebagaimana telah disampaikan bahwa kodifikasi bertujuan untuk mencapai kesatuan, kepastian hukum, dan penyederhanaan hukum. Karateristik politik hukum nasional dengan cara kodifikasi jika ditarik mundur kebelakang bisa dilihat pada rumusan GBHN pada butir (c) TAP MPR Nomor IV/MPR 1978 tentang Garis-garis Besar Haluan Negara, yang berbunyi: "Peningkatan dan penyempurnaan pembinaan hukum nasional, dengan antara lain mengadakan pembaharuan kodifikasi serta unifikasi hukum di bidang-bidang tertentu dengan jalan memperhatikan kesadaran hukum dalam masyarakat." 46 Era reformasi ini, kodifikasi hukum menjadi program legislasi pemerintah bersama DPR.

Begitu juga konsep omnibus law tidak bisa disamakan dengan unifikasi hukum, karena unifikasi merupakan penyatuan hukum yang berlaku secara nasional atau penyatuan pemberlakuan hukum secara nasional. Unifikasi hukum adalah suatu langkah penyeragaman hukum atau penyatuan suatu hukum untuk diberlakukan bagi seluruh negara sebagai hukum nasional, sehingga tujuannya untuk lebih menjamin kepastian hukum dalam arti kepastian berlakunya suatu hukum bagi seluruh masyarakat. Sebagai contoh unifikasi hukum adalah UndangUndang Nomor 1 Tahun 1974 tentang Perkawinan (UU Perkawinan) karena di setiap wilayah Indonesia memiliki adat tersendiri dalam perkawinan. Oleh karenanya, dibentuklah Undang-undang Perkawinan 
sebagai penyatuan dan penyeragaman hukum untuk diberlakukan di negara Indonesia sebagai hukum nasional.

Model hukum yang dikenal Indonesia selanjutnya adalah kompilasi hukum Islam, sedangkan pengertian kompilasi hukum Islam secara etimologis ialah kumpulan/ himpunanyang tersusun secara teratur. Adapun secara terminologi kompilasi diambil dari kata compilation (Inggris) atau compilatie (Belanda) yangdiambil dari kata compilare, artinya mengumpulkan bersamasama, seperti mengumpulkan peraturanperaturan yang tersebar dimana-mana, istilah ini kemudian dipergunakan dalam bahasa indonesia kompilasi, sebagai terjemahan lansung. ${ }^{47}$ Kompilasi merupakan suatu kegiatan pengumpulan dari berbagai bahan yang tertulis yang diambil dari berbagai buku maupun tulisan mengenai suatu persolan tertentu. Pengumpulan bahan dari berbagai sumber yang dibuat oleh beberapa sumber yang berbeda untukditulis dalam suatu buku tertentu, sehingga dari kegiatan itu semua bahan yang diperlukan akan dapat ditemukan dengan lebih mudah. ${ }^{48}$ Oleh karena itu, norma hukum sangat berbeda dengan undangundang dengan konsep omnibus law, karena kompilasi hukum Islam menggambarkan ragam kehidupan masyarakat Islam Indonesia terutama adanya norma hukum yang hidup dalam masyarakat yang berperan serta mengatur interaksi sosial dan aktualisasi normatif dari eksplanasi fungsional ajaran Islam yang berimplikasi terpenuhinya tuntutan kebutuhan hukum yang merupakan kesepakatan para ulama.

\section{Penerapan Undang-Undang dengan Konsep Omnibus Law}

Pembahasan rancangan undang-undang dengan konsep omnibus law yang dilakukan Pemerintah bersama DPR mengupayakan rancangan undang-undang di bidang ekonomi seperti Rancangan Undang-Undang tentang Penciptaan Lapangan Kerja dan Perpajakan. Kedua Rancangan Undang-undang dengan konsep omnibus law tersebut disusun dengan tujuan untuk memperkuat ekonomi nasional melalui perbaikan regulasi agar iklim investasi membaik. Pemerintah beranggapan bahwa peraturan perundang-undangan yang ada dengan ribuan pasal tersebut telah menghambat investasi di Indonesia, sehingga perlu ada perubahan di bidang hukum.

Pembahasan rancangan undang-undang omnibus law Penciptaan Lapangan Kerja dan Perpajakan harus dilakukan dengan penuh kehati-hatian dan partisipatif, perlu ada proses public hearing serta tidak tergesagesa dengan mengutamakan kepentingan bangsa dan negara di atas kepentingan bisnis kelompok tertentu, apalagi kepentingan asing. Materi muatan rancangan undangundang Omnibus Law Penciptaan Lapangan Kerja dan Perpajakan harus memperhatikan norma hukum dalam sistem hukum nasional dengan Pancasila dan UUD 1945 sebagai sumber hukumnya. Di samping itu juga tidak selalu membatalkan norma hukum dalam undang-undang lain yang sudah ada. Konsep omnibus law yang diterapkan di Indonesia harus merupakan karakter budaya bangsa Indonesia, sehingga perlu ada pemilahan norma hukum yang akan diberlakukan. Oleh

\footnotetext{
47 Abdurrahman, Kompilasi Hukum Islam di Indonesia, (Jakarta : Akademika Pressindo,1992), hlm. 11.

$48 \quad$ Ibid, hlm. 12.
} 
karena luasnya objek hukum yang harus diatur dalam satu undang-undang, dengan banyak pasal-pasal, maka norma hukumnya harus bersesuaian dengan norma hukum dengan undang-undang lain.

Berbagai objek hukum yang disatukan dengan banyaknya pasal bahkan sampai bisa membatalkan undang-undang lain, maka model undang-undang dengan konsep omnibus law ini seperti Undang-undang Konsolidasi. Undang-undang Konsolidasi ini mengatur berbagai objek dengan norma hukum yang akan diharmonisasikan. Apabila undang-undang dengan konsep omnibus law diterapkan, maka dalam konteks hierarki peraturan perundang-undangan inilah eksistensi undang-undang konsolidasi (consolidation law) dapat diperlukan guna mengisi celah sistematisasi hukum dalam sistem peraturan perundang-undangan.

Selain itu, undang-undang dengan konsep omnibus law akan berimplikasi pada penegakan hukum yang sangat lemah, karena akan mempersulit aparat penegak hukum itu sendiriuntuk mengambil kewenangan dalam penegakan hukum. Oleh karena luasnya materi muatan yang terdapat dalam undang-undang dengan konsep omnibus law mengakibatkan kesulitan bagi aparat penegak hukum untuk menegakkannya. Dengan demikian, pembentuk undangundang perlu memperhatikan dengan memperkuat penegakan hukum, sehingga dapat menunjukkan bagaimana penegakan hukum di Indonesia tidak akan timpang.

Perlu diperhatikan asas hukum dalam sistem hukum di Indonesia, yaitu asas lex posterior derogat legi priori. Asas lex posterior derogat legi priori ini tentu akan mempersulit keberlakuan undang-undang dengan konsep omnibus law, undang-undang yang disahkan belakangan akan tetap bisa menyampingkan undang-undang dengan omnibus law jika materi muatannya berbeda.

Begitu juga permasalahan mengenai teori peraturan perundang-undangan yang dikenal dalam Undang-undang Nomor 12 Tahun 2011 tentang Pembentukan Peraturan Perundangundangan sebagaimana diubah dengan Undang-undang Nomor 15 Tahun 2019. Kedudukan undang-undang dengan konsep omnibus law harus diberikan legitimasi dalam Undang-Undang Nomor 12 Tahun 2011 tentang Pembentukan Peraturan Perundangundangan sebagaimana diubah dengan Undang-undang Nomor 15 Tahun 2019. Hal ini, apabila tidak mendapat legitimasi menurut Undang-Undang Nomor 12 Tahun 2011 tentang Pembentukan Peraturan Perundang-undangan sebagaimana diubah dengan Undang-undang Nomor 15 Tahun 2019, maka undang-undang dengan konsep omnibus law tersebut bertentangan dengan Undang-Undang Nomor 12 Tahun 2011 tentang Pembentukan Peraturan Perundangundangan sebagaimana diubah dengan Undang-Undang Nomor 15 Tahun 2019.

Dengan demikian yang harus dilihat bagaimana isi norma hukum di dalam undangundang dengan konsep omnibus law, yaitu apakah bersifat umum atau khusus seperti undang-undang biasa, apabila bersifat khusus, maka tidak semua ketentuan yang dicabut melainkan hanya yang bertentangan saja. Akan tetapi apabila ketentuannya umum akan menjadi masalahapabila dibenturkan dengan asas lex spesialis derogat legi generalis (aturan yang khusus mengesampingkan aturan yang umum). Oleh sebab itu, harus diatur dalam 
hierarki peraturan perundang-undangan perihal kedudukannya.

\section{Penutup}

Sebagai penutup diambil kesimpulan bahwa undang-undang dengan konsep omnibus law, dimaksudkan sebagai suatu undang-undang yang dibuat untuk menyasar berbagai objek menjadi satu isu besar yang mungkin dapat mencabut atau mengubah beberapa undang-undang sekaligus. Dengan demikian undang-undang dengan konsep omnibus law yang dibuat merupakan model hukum baru atau suatu paradigma baru dalam peraturan perundang-undangan di Indonesia. Oleh karena suatu paradigma baru dalam peraturan perundang-undangan di Indonesia, maka undang-undang dengan konsep omnibus law yang dibuat akan mengubah sistem peraturan perundang-undangan, karena konsep dan teorinya berbeda dengan model hukum dan norma hukum yang selama ini berlaku di Indonesia.

Sebagai saran penulis, maka apabila pemerintah bersamaDPR bersepakatmembuat undang-undang dengan konsep omnibus law terutama di bidang perekonomian, sebaiknya Undang-undang Nomor 12 Tahun 2011 tentang Pembentukan Peraturan Perundang-undanan sebagaimana diubah dengan Undang-undang Nomor 15 Tahun 2019 juga harus diubah, karena undang-undang tersebut merupakan dasar atau pedoman dalam pembentukan peraturan perundang-undangan. Begitu juga perlu mengikuti proses prolegnas yang normal, tidak tergesa-gesa dan melibatkan stakeholder serta masyarakat, sehingga keberlakuan suatu undang-undang dapat memenuhi kriteria undang-undang dengan proses pembentukan peraturan perundangundangan yang baik dan benar.

\section{Daftar Pustaka}

\section{Buku}

Abdurrahman, KompilasiHukum Islam di Indonesia, (Jakarta:Akademika Pressindo,1992).

Amiruddin dan Zainal Asikin, Pengantar Metode Penelitian Hukum, (Jakarta:Raja Grafindo Persada, 2006).

Anggono, Bayu Dwi, Perkembangan Pembentukan Undang-undang di Indonesia, (Jakarta: Konstitusi Press, 2014).

Asshiddiqie, Jimly, Perihal Undang-Undang, (Jakarta, Rajawali Pers, 2010).

Baker, Charles Arnold, The Companion to British History, s.v. Civilian, (London: Rotledge, 2001).

Bentham, Jeremy, Teori Perundang-undangan, Prinsip-prinsip Hukum Perdata dan Hukum Pidana (The Theory of Legislation), diterjamahkan oleh Nurhadi, MA, (Bandung: Nusamedia, 2010).

Eddyono, Supriyadi Widodo, et.al, (Penyusun), Melihat Rencana Kodifikasi dalam RKUHP: Tantangan Upaya Pembaruan Hukum Pidana di Indonesia, (Jakarta: Institute for Criminal Justice Reform, 2015).

Hadjon, Philipus M. dan Tatiek Sri Djamiati, Argumentasi Hukum (Yogyakarta: Gadjah Mada Unversity press, 2005).

Hariri, Wawan Muhwan, Pengantar IImu Hukum, (Bandung: Pustaka Setia, 2012).

Indrati, Maria Farida, Ilmu Perundang-undangan, Dasar-Dasar dan Pembentukannya, (Yogyakarta: Kanisius, 1998).

.......... Ilmu Perundang-undangan, Jenis, Fungsi dan Materi Muatan, (Yogyakarta, Kanisius, 2007).

Manan, Bagir, Dasar-Dasar Perundang-undangan Indonesia, (Jakarta: Ind-Hill-Co, 1992).

Marzuki, Peter Mahmud, Pengantar IImu Hukum, (Jakarta: Pranada Media Group, 2008).

Purbacaraka, Purnadi dan Soerjono Soekanto, Perihal Kaidah Hukum, (Bandung: Alumni, 1989).

Rauta, Umbu, Konstitusionalitas Pengujian Peraturan Daerah, (Yogyakarta, Genta Publishing, 2016).

Soehino, Hukum Tatanegara, Teknik Perundangundangan, (Yogyakarta, Liberty, 1990). 
Soekanto, Soerjono dan Sri Mamudji, Penelitian Hukum Normatif-Suatu Tinjauan Singkat, (Jakarta: Raja Grafindo Persada, 1994).

Soemardi, Dedi, Pengantar Hukum Indonesia, (Jakarta: Ind-Hill Co., 1997).

Tim Pengajar Hukum Pidana UI, Position Paper (RKUHP Kodifikasi atau Kompilasi), (Jakarta: Bidang Studi Hukum Pidana UI, 2014).

\section{Makalah/Artikel/Prosiding/Hasil Penelitian}

Abdullah, Abdul Gani, Pengantar Memahami Undang-Undang Jurnal Legislasi, Volume I No. 2, (September 2004).

Black's Law Dictionary, West Publishing Wo, (2004).

Rasjidi, Lili dan Liza Sonia Rasjidi, Monograf: Filsafat IImu, Metode Penelitian, Dan Karya Tulis IImiah Hukum, (Bandung, 2009).

Keyzer, Patrick, "The Indonesian Omnibus Law: Opportunities and Challenges", Kuliah Umum, Universitas Brawijaya, (Malang, 29 January 2020).

Magnar, Kuntana,Hubungan Dewan Perwakilan Rakyat (DPR) Dengan Presiden Setelah Perubahan Undang-Undang Dasar (UUD) 1945: Pencarian Bentuk dan Isi, Disertasi, Universitas Padjadjaran (Bandung, 2006).

MD, M Mahfud dalam sambutannya pada Acara Law \& Regulation Outlook 2020 di Hotel Shangri-La, Jakarta Pusat, (Rabu 22 Januari 2020).

Shidarta, B. Arief, "Pembentukan Hukum di Indonesia", Makalah disampaikan dalam Rapat Kerja Panitia Khusus DPR RI Rancangan Undang-Undang tentang Pembentukan Peraturan Perundang-undangan, Rapat Dengan Pendapat Umum dengan para Pakar, (Rabu, 26 Januari 2011).

\section{Internet}

http://kanal24.co.id/read/patrick-keyzeromnibus-law-menambah-kompleksitashukum-indonesia. (diunduh, Rabu, 6 Februari, 2020).

https://www.wartaekonomi.co.id/read260634/ apa-itu-omnibus-law, (diunduh, Rabu, 6 Februari 2020).

https://business-law.binus.ac.id/2019/10/03/ memahami-gagasan-omnibus-law/, (diunduh, Senin, 3 February 2020). https://nasional.sindonews.com/ $\mathrm{read} / 1509229 / 16 / \mathrm{serikat}$-pekerjatolakomnibus-law-1580140561, (diunduh, Senin, 3 Februari 2020).

https://www.wartaekonomi.co.id/read260634/ apa-itu-omnibus-law, (diunduh, Rabu, 6 Februari 2020).

https://www.hukumonline.com/berita/baca/ It5e2c1e4de971a/menelusuri-asal-usulkonsep-omnibus-law/, (diunduh Senin, 3 February 2020).

https://business-law.binus.ac.id/2019/10/03/ memahami-gagasan-omnibus-law/, (diunduh, Senin, 3 Februari 2020).

h t t p s:// e conomy.okezone.com / $\mathrm{read} / 2020 / 01 / 22 / 320 / 2156470 / o m n i b u s-$ law-itu-apa-ini-jawabannya, (diunduh, Senin, 3 February 2020).

https://id.wiktionary.org/wiki/undang-undang_ pokok, (diunduh, Senin, 10 Februari 2020).

https://jambi-independent.co.id/ read/2016/12/20/11955/polemikundangundang-payung/, (diunduh, Senin, 10 Februari 2020).

\section{Peraturan}

Undang-Undang Dasar Negara Republik Indonesia Tahun 1945.

Undang-undang Nomor 5 Tahun 1960 Tentang Peraturan Dasar Pokok-pokok Agraria.

Undang-undang Nomor 12 Tahun 2011 tentang Pembentukan Peraturan Perundangundangan.

Undang-undang Nomor 32 Tahun 2009 tentang Perlindungan dan Pengelolaan Lingkungan Hidup.

Undang-undang Nomor 15 Tahun 2019 tentang Perubahan atas Undang-undang Nomor 12 Tahun 2011 tentang Pembentukan Peraturan Perundang-undangan. 